\title{
DIE VROEë BELYDENISSE AANGAANDE JESUS IN DIE NUWE TESTAMENT1
}

\author{
G.J.C. Jordaan \\ Departement Nuwe Testament \\ Potchefstroomse Universiteit vir CHO \\ POTCHEFSTROOM
}

\begin{abstract}
In 50 different instances in the (jospels and Acts confessions about Jesus are expressed. A synopsis of these confessions indicates that these confessions reflect on the question about who Jesus really is. Furthermore it is revealed that the contents of these confessions ultimately represent only three basic confessions about Jesus: (1) Jesus is the Christ, (2) Jesus is the Son of God, and (3) Jesus is the Lord. Thesc basic confessions are augmented by three other more detailed confes. sions, in which Jesus is confessed to be (4) God Himself, (5) our Soviour, and (6) the Judge of the living and the dead. It is maintained that the Gospels and Acts state that God, through his Spinit and his Word, gave these inuths about Jesus to his Church to confess. That these tnuths are indeed confessed by the Chunch, is cvident from a survey of the Apostles' Creed, the Nicene Creed and the Athanasian Creed, as well as the Bclgic Confession, the Heidelberg Catechism and the Canons of Dordt.
\end{abstract}

\section{INLEIDING}

\subsection{Probleemstelling en aktualiteit}

In die Nuwe Testament is daar sprake van verskillende vorme van belydenisse wat bely word (Van Rensburg, 1991:160-166). Hieronder neem die belydenisse wat aangaande Jesus bely word, uiteraard 'n baie belangrike plek in (vgl. Cullmann, 1943:33-34). In Matteus 10:32,33 (Luk. 12:8,9) sê Jesus self hoe belangrik dit is om in Hom te bely:

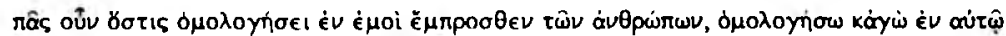

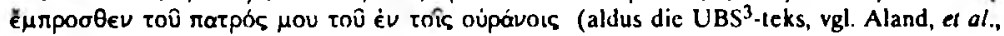
1983).

"Elkeen dan wat My sal bely yoor die mense, hom sal Ek ook bely voor my Vader wat in die hemele is."

${ }^{1}$ Hierdic artikel vorm decl van dic recks artikels oor dic belydenis en die belydenisskrifte. Kyk sok In die Skriflig $25(1) 1991$. 
Belydenis in Jesus is vir die mens van lewensbelang.

Die uitdrukking belydenis in Jesus val ietwat vreemd op die oor. Dit is 'n direkte

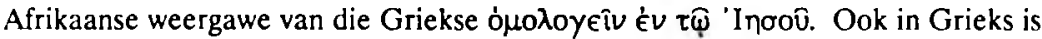

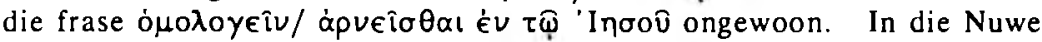
Testament kom die frase slegs in Matteus 10:32,33 voor (en as parallel daarvan Lukas 12:8,9). Hierdie uitdrukking is 'n tipiese Semitisme (Moulton et al., 1976:110) waarin die év met die datief dui op die persoon in verband met wie die handeling plaasvind (Meyer, 1877:303; Blass \& Debrunner, 1975:118; Kittel, 1978:211). Belydenis in iemand kom dus op dieselfde neer as belydenis aangaande iemand. 'n Belydenis in Jesus is dus in wese 'n belydenis wat in verband met Jesus of aangaande Jesus bely word ${ }^{2}$.

'n Belangrike saak om uit te maak, is wat die belydenis in of aangaande Jesus presies behels. Leksikograwe is dit eens dat die uitdrukking belydenis in (aangaande) iemand oor die algemeen daarna verwys dat iemand erken word vir wie of wat hy is (vgl. Bauer, 1958:1125; Blass-Debrunner, 1975:118; Kittel, 1978:211; Louw \& Nida, 1989:419). Hieruit sou afgelei kon word dat die NuweTestamentiese belydenisse aangaande Jesus geloofsuitsprake oor Jesus is waarin Hy erken word vir wie en wat Hy is.

Uit die literatuur blyk dit egter dat daar nie eenstemmigheid onder NuweTestamentici bestaan oor wat presies die inhoud, die aard en die oorsprong van die belydenisse aangaande Jesus is nie. Neufeld (1963:2-12) bied 'n kort oorsig oor hoe veral die vorm-kritiese benadering enersyds en die heilshistoriese benadering andersyds teen die helfte van hierdie eeu tot botsende standpunte oor die inhoud, aard en oorsprong van die Christelike belydenis oor die algemeen gelei het. Sedertdien is die debat voortgesit deur skrywers soos Wengst (1967:97-110) wat die Nuwe-Testamentiese belydenisse oor Jesus as deel van die vroeg-Christelike tradisie beskou, Ebeling (1967:241) wat beweer dat in die Nuwe-Testamentiese belydenisse Jesus self nie inhoud van die geloof is nie maar dat Hy slegs oorsprong van die geloof was, Kelly (1971:6-29) wat van oordeel is dat die Christologiese belydenisse in die Nuwe Testament uiteenlopend van aard is, en Marcus (1989:123-141) wat 'n Joodse agtergrond by die Nuwe-Testamentiese belydenisformules in verband met die Christus bespeur.

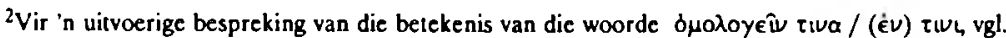
Van Rensburg se artikel elders in hierdie uitgawe.
} 
Dit is ook duidelik dat die beskouing oor die inhoud, aard en oorsprong van die belydenisse (aangaande Jesus) van groot belang is vir die siening oor die verhouding tussen belydenis, die geloof en die belydenisskrifte (vgl. Kuitert, 1977:74 e.v.).

\subsection{Doel en afbakening}

Die doel van hierdie artikel is om aan te dui wat die inhoud, aard en oorsprong van die belydenis aangaande Jesus is soos dit in die Nuwe Testament voorkom. In samehang hiermee word beoog om vas te stel wat die verhouding tussen die belydenis in Jesus, die geloof en die belydenisskrifte is.

Aangesien hierdie artikel op die vroeë Jesus-belydenisse toegespits is, word die aandag grootliks bepaal by die belydenisse wat in die Evangelies en Handelinge opgeteken is. Gegewens uit die res van die Nuwe Testament word daarom slegs vir toeligting in berekening gebring, en as studiemateriaal vir moontlike verdere navorsing oor hierdie onderwerp aangetoon.

Die feit dat hierdie artikel deel van 'n reeks artikels vorm wat almal oor die belvdenis(skrifte) handel, bied op sigself 'n verdere afbakening ten opsigte van die veld van ondersoek. Wat die studie van belydenisse in die Nuwe Testament aanbetref, word byvoorbeeld nie in hierdie artikel besondere aandag aan betekenisdefiniëring en begripsbepaling gegee nie maar word aangesluit by 'n artikel van J.J.J. van Rensburg elders in hierdie uitgawe waarin hy uitvoerig aandag gee aan die bepaling van Griekse woorde vir die begrip bely/belydenis en die definiëring van die betekenisse van sodanige woorde 3 .

\subsection{Opset}

In hierdie artikel word die belydenisse angaande Jesus openbaringshistories bestudeer. Hiervolgens word die groeiende lyn van belydenisse vanaf die eerste identifiseerbare belydenis deur Jesus se dissipels tot by die belydenisse deur die eerste gemeentes (Handelinge) nagegaan. Met die oog daarop word aandag gegee aan die volgende sake:

- die voorkoms van belydenisse in die Evangelies en Handelinge;

* die aard van die belydenis in Jesus;

${ }^{3} \mathrm{~V}_{\mathrm{g} I .}$ Van Rensburg, J.J. "Die begrip bely/belydenis in die Nuwe Testament." 
- die inhoud van die belydenis;

* die oorsprong van die belydenis;

* die verhouding van die belydenis tot die geloof;

- die verhouding van die belydenis tot die belydenisskrifte.

\section{DIE VOORKOMS VAN BELYDENISSE IN DIE EVANGELIES EN HANDELINGE}

Die doel van hierdie studie vereis dat vooraf vasgestel moet word watter belydenisse aangaande Jesus wel in die Evangelies en Handelinge voorkom. Sodanige opname kan natuurlik nie beperk word tot plekke in die Evangelies en Handelinge waar die

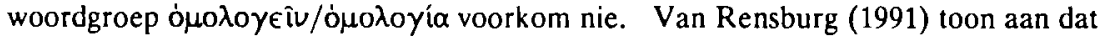

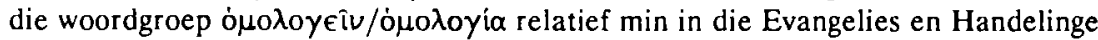
aangetref word, en daarby nie altyd in die betekenisveld van bely/belydenis nie. Terselfdertyd is daar op heelwat plekke in die Evangelies en Handelinge belydenisse opgeteken sonder dat pertinent daarna verwys word as 'n ópoגoyía wat iemand

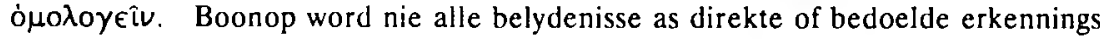
uitgespreek nie, maar dikwels word daar slegs per implikasie iets aangaande Jesus erken, verkondig of getuig.

In die lig hiervan is dit baie belangrik om vir hierdie opname 'n maatstaf te hê waaraan 'n uitspraak gemeet kan word of dit wel as 'n belydenisuitspraak beskou kan word of nie. Met die oog hierop is die vorm waarin belydenisse voorkom, van groot waarde. Die volgende waarnemings in verband met die vorm van belydenisse in die Evangelies en Handelinge is van belang:

Belydenisuitsprake word deur die Evangelieskrywers en ook in Handelinge gewoonlik in die direkte rede weergegee maar soms ook in die indirekte rede. Wat uitsprake in die indirekte rede betref, toon Neufeld (1963:70, 105 e.v.) aan dat belydenisse dikwels geformuleer word deur 'n voorwerpsin (ótı met die indikatief, of akkusatief en infinitief, of bloot die akkusatief) ingelei deur 'n woord wat betekenisverwant is aan die ó $\mu$ oגoyía-begrip, byvoorbeeld

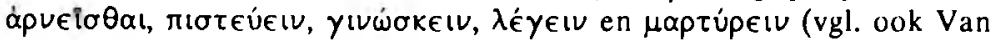
Renshurg, 1991). Sulke konstruksies kan belydenisformules genoem word (vgl. Wengst, 1967:97; Neufeld, 1963:120).

Uitgaande van sodanige belydenisformules is onderstaande opname van uitsprake aangaande Jesus in die Evangelies en Handelinge gedoen. In die opname is nie alle uitsprake aangaande Jesus as belydenisse beskou nie maar slegs dié uitsprake wat 
binne die bovermelde raamwerk van belydenisuitsprake beskrywe is. Ter wille van latere verwysing word daar tussen direkte en geimpliseerde belydenisse onderskei. In die volgende plekke word dar sodanige belydenisse in die Evangelies en Handelinge aangetref:

\subsection{Direkte belydenisuitsprake}

\section{Matteus}

14:33 Na die stilmaak van die storm val dié wat in die skuit was voor Hom neer en sê: Waarlik, $U$ is die Seun van God!

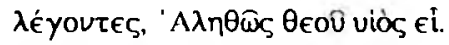

16:16 Petrus se belydenis: $U$ is die Christus, die Seun van die lewende God.

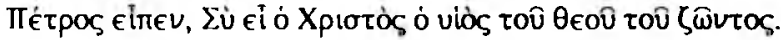

Markus

8:29 Petrus se belydenis: $U$ is dic Christus.

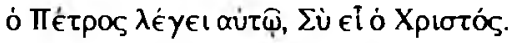

15:39 Die offisier by die kruis sê: Waarlik, Hy was die Seun van God.

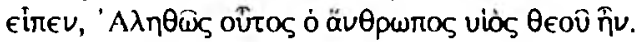

Lukas

9:20 Petrus se belydenis: Die Christus van God!

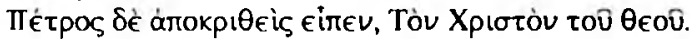

Johannes

1:29 Johannes sê: Dáár is die Lam van God wat die sonde van die wêreld wegneem!

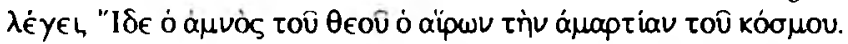

1:49) Natanael sê vir Hom: Rabbi, $U$ is die Seun van God, die Koning van Israel.

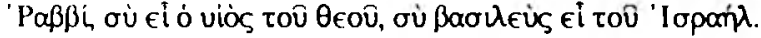

4:42 Die Samaritane het gesê: Ons weet dat Hy waarlik die Saligmaker van die wêreld is.

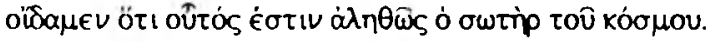

6:69 Petrus antwoord Hom: Ons het geglo en erken dat $U$ die heilige van God is (die meeste bronne: dat $U$ die Christus is, die Seun van die lewende God).

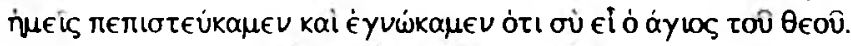

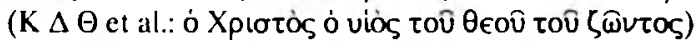

7:41 Ander het gesê: Hy is die Christus.

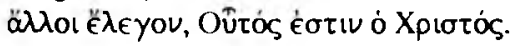


11:27 Maria antwoord Hom: Ja, Here, ek glo dat $U$ die Christus is, die Seun van God, wat in die wêreld sou kom.

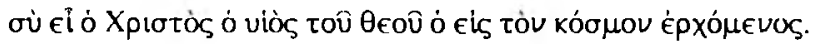

20:28 Tomas sê vir Hom: My' Here en my God!

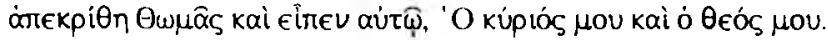

\section{Handelinge}

In die boek Handelinge geskied die belydenis aangaande Jesus merendeel in die vorm van verkondiging:

2:36 Petrus op Pinkster: Ialat dan die hele huis van Israel sekerlik weet dat God

Hom Here en Christus gemaak het, hicrdie Jesus wat julle gekruisig het.

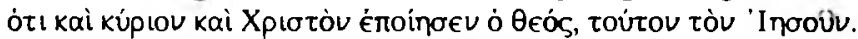

5:42 Die apostels het die evangelie verkondig dat Jesus die Christus is.

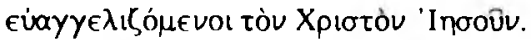

9:20 Saulus het Christus in die sinagoges verkondig dat Hy die Seun van God is.

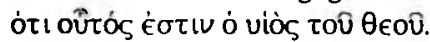

10:42 Paulus aan Cornelius: God het ons bevel gegee om ... met krag te hetuig dat dit Hy (Jesus) is wat deur God bestem is as Regter van lewende en dode.

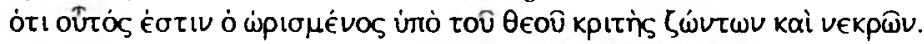

11:20 Die gelowiges van Ciprus en Cirene het verkondig dat Jesus die Here is.

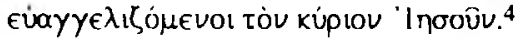

17:3 Paulus het gesê: Hierdie Jesus wat ek aan julle verkondig, is die Christus.

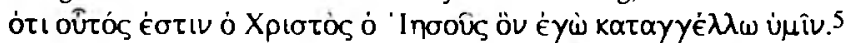

18:5 Paulus het aan die Jode betuig dat Jesus die Christus is.

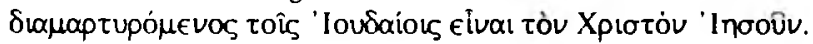

18:28 Apollos het deur die Skrifte bewys dat Jesus die Christus is.

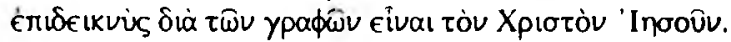

\footnotetext{
${ }^{4}$ Dic woorde tóv kúpıov 'I nonûv kan beskou word as blote dirckte voorwerp van

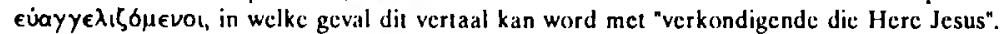
Indicn dit as 'n voorwerpsin met ellipticse eivat beskou word, dra dit die betckenis van "verkondigende dat Jesus dic Here is". Saam met Neufeld (193:119) kics ek laasgenoemde moontlikhcid.

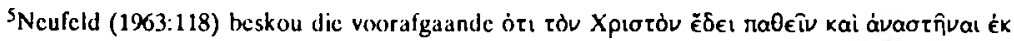

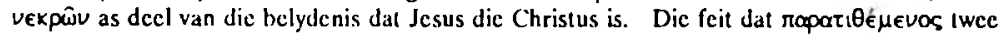

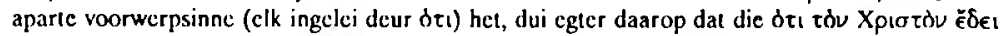

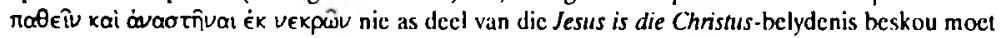
word nie maar as 'n aparte verkondiging, en voorwerp van ropart $\theta$ éjevos.
} 
2.2 Geïmpliseerde belydenisse

Matteus

4:3,6 Die duiwel by die versoeking: As $U$ die Seun van God is ...

Ei viós €i toû $\theta$ eô...

12:23 Die verbaasde skare sê: Is Hy nie miskien die Seun van Dawid nie?

Mñ

16:20 Jesus beveel sy dissipels om vir niemand te sê dat Hy die Christus is nie.

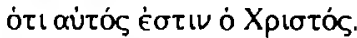

17:5 Die verheerliking op die herg: Dit is my geliefde Seun in wie Ek 'n welbehae het.

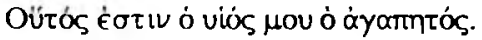

26:63 Die hoëpriester eis: Sê vir ons of $U$ die Christus, die Seun van God, is!

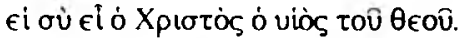

27:17,22 Pilatus verwys na Hom as: Jesus wat genoem word Christus.

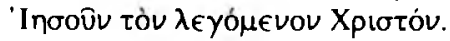

27:40,43 Die spot van die skare: As $U$ die Seun van God is, kom af van die kruis!

Hy het mos gesê: $E k$ is die Scun van God.

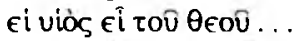

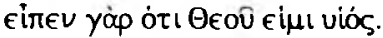

Markus

3:11 Die onreine geeste skreeu: $U$ is die Scum van God!

¿ù ể ò viòs roú $\theta \epsilon$ oû.

9:7 By die verheerliking op die berg: Dit is my geliefde Seun, luister na Hom!

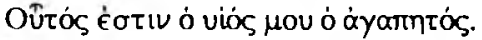

14:61 Die hoëpriester vra: Is $U$ dic Christus, die Seun van die geseënde God?

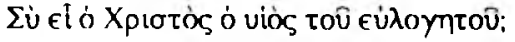

Lukas

4:3,9 Die duiwel by die versoeking: As $U$ die Seun van God is ...

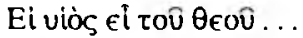

4:41 Die demone skreeu: $U$ is die Christus, die Seun van God!

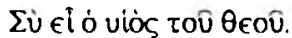

9:35 By die verheerliking op die berg: Dit is my geliefde Seun, luister na Hom!

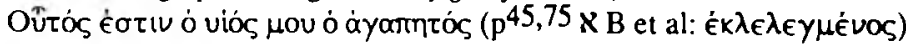

22:70 Die Sanhedrin vra: Is $U$ dan die Seun van God?

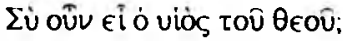

23:2 Die beskuldiging van die Jode: Hy sê dat Hy self Christus, die Koning, is.

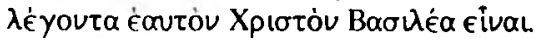


23:35 Die spot van die skare: Laat Hy Homself verlos as Hy die uitverkore Christus van God is!

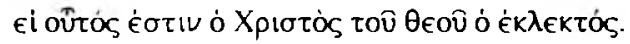

Johannes

1:20 Johannes die Doper "bely": Ek is nie die Christus nie.

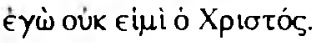

1:41 Andreas sê vir Simon: Ons het die Messias gevind.

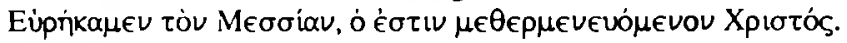

7:26 Die inwoners vra: Sou die owerstes weet dat Hy die Christus is?

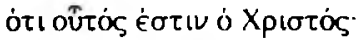

9:22 Wie Hom as Christus bely het, is uitgeban uit die sinagoge.

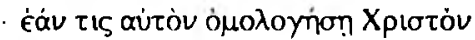

10:36 Jesus het gesê: Ek is die Seun van God.

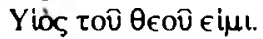

18:33 Pilatus sê vir Hom: Is U die Koning van die Jode?

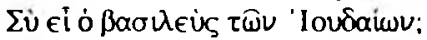

19:19-22: Pilatus se opskrif bo die kruis: Jesus, die Nasarener, die Koning van die Jode.

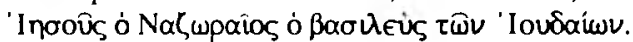

20:31 Hierdie dinge is geskrywe sodat ju!le kan glo dat Jesus die Christus is, die Seun van God.

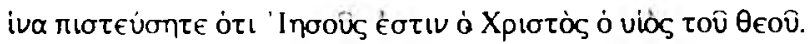

Handelinge

9:5 (22:8; 25:15) Op Paulus se vraag: "Wie is U, Here?" antwoord die Here: "Ek is

Jesus wat jy vervolg."6

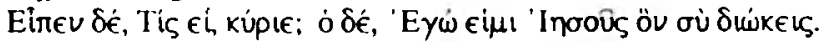

Hierdie opname bring 'n totaal van 50 waarneembare belydenisuitsprake aangaande Jesus in die Evangelies en Handelinge aan die lig. Van die 50 uitsprake aangaande Jesus word 20 gestel met die direkte bedoeling om iets aangaande Jesus te bely, terwyl die oorblywende 30 in die vorm van geimpliseerde belydenisse aangetref word.

${ }^{6}$ Neufeld (1963:120) wil hicrdie woorde nie as 'n geımpliseerde belydenis van Jesus as dic xúpıos aanvaar nie, aangesicn die vokaticf xúple as blote hollike aanspreckvorm beskou kan word. Tog is Paulus se optrede by dic Damaskusgebeure tol so 'n matc bewys van sy crkenning dat Jesus dic Here is, dat sy woorde ongetwyleld 'n belydenis van Jesus se xúplos-skap impliseer (vgl. Floor, 1982:23). 


\section{DIE AARD VAN DIE BELYDENIS IN JESUS}

In die lig van bostaande opname kan vervolgens op die aard en die inhoud van die Jesus-belydenisse ingegaan word. Die inhoud van die belydenisse word in punt 4 hier onder bespreek. Wat die aard van die belydenisse betref, word daarop gewys dat elk van die belydenisse wat hierbo aangetoon is, as belydenis uitgeken word omdat dit as bepaalde vorm van kommunikasie ${ }^{7}$ figureer, naamlik diê van erkenning/ ontkenning, getuienis en verkondiging 8 . Die belydenisse in die Evangelies en Handelinge kan dus getipeer word as erkenning, as getuienis en as verkondiging.

\subsection{Die belydenis as 'n erkenning}

In sy eenvoudigste vorm behels 'n belydenis aangaande Jesus 'n optrede wat daarin bestaan dat mondeling erken word wie of wat Hy is (vgl. Van Rensburg, 4.2). Sodanige erkenning kan in die openbaar geskied (byvoorbeeld deur 'n deel van die skare, vgl. Johannes 7:41), of in 'n private gesprek (bv. Natanael, vgl. Johannes 1:49); dit kan 'n antwoord op 'n vraag wees (bv. Petrus, vgl. Matteus 16:16), of dit kan 'n spontane erkenning wees (byvoorbeeld deur die dissipels in die skuit na die stilmaak van die storm; vgl. Matteus 14:33).

Dikwels is die belydenis nie 'n uitdruklike erkenning nie, maar 'n geïmpliseerde erkenning. Dit vind ons in gevalle waar iemand nie werklik bedoel om in soveel woorde iets aangaande Jesus te bely nie, maar waar sy woorde tog per implikasie 'n erkenning aangaande Jesus bevat. 'n Voorbeeld hiervan vind ons by Johannes die

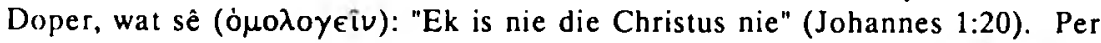
implikasie sê hy dat die Een wat na hom kom, wel die Christus is. Ook die hoëpriester, waar hy aan Jesus vra: "Is U die Christus, die Seun van God?" (Markus 14:61), erken per implikasie dat Jesus bely kan word as die Christus, die Seun van God. Iń die Evangelies is daar ook insidente aangeteken waar die belydenis aangaande Jesus vermeld word juis by wyse van verwerping van die belydenis. Die skare om die kruis wat ontken dat Jesus die Seun van God is, sê spottenderwys: "As U die Seun van God is, kom af van die kruis!" Daarmee word per implikasie erken dat Jesus volgens sommige as die Seun van God kwalifiseer.

\footnotetext{
${ }^{7}$ Domein 33, volgens Louw \& Nida, vgl. Van Rensburg (1991).

${ }^{8}$ Louw \& Nida se Subdomeine R-V, vgl. Van Rensburg (1991).
} 


\subsection{Die belydenis as verkondiging}

In onderskeiding van die belydenis as 'n erkenning, vind belydenisse dikwels in die vorm van verkondiging plaas, dit wil sê waar iemand 'n belydenis aangaande Jesus uitspreek spesifiek met die doel om ander te oorreed (vgl. Van Rensburg 4.2).

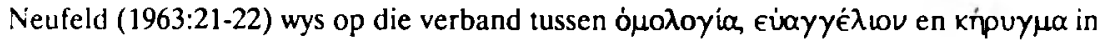
die Nuwe Testament. Hy toon aan dat die inhoud van die evangelie wat verkondig word, in die vroeë kerk saamtrek in die persoon van Jesus.

In die Evangelies en Handelinge word verskeie belydenisse by wyse van verkondiging uitgespreek. Hieronder sou die getuienis van Johannes die Doper gereken kon word: "Daar is die Lam van God wat die sonde van die wêreld wegneem" (Johannes 1:29). In die boek Handelinge word belydenisse aangaande Jesus meermale as kerugma verkondig, byvoorbeeld in Petrus se toespraak by Pinkster: "Laat dan die hele huis van Israel weet dat God Hom Here en Christus gemaak het, hierdie Jesus wat julle gekruisig het" (Handelinge 2:36), en Paulus in Tessalonika: "Hierdie Jesus wat ek aan julle verkondig, is die Christus" (Hand. 17:3).

Die Jesus-belydenis dra dus meermale in die Evangelies en Handelinge 'n onteenseglik kerugmatiese karakter. Jesus is die inhoud van die kerugma wat geproklameer word. Hy is die inhoud van die evangelie wat verkondig word.

\subsection{Die belydenis as 'n getuienis}

Die belydenis aangaande Jesus kan ook verkondig word as 'n getuienis ( $\mu \alpha \rho \tau u p i \alpha$ ). In Johannes 1:15 word die prediking van Johannes die Doper getipeer as 'n getuienis

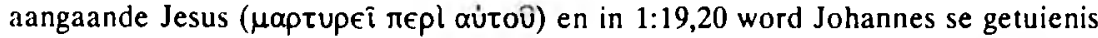
direk aan die Jesus-belydenis verbind. In 1:32-34 word Johannes se getuienis

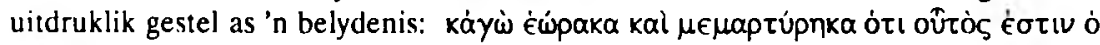
viòs тoิิ $\theta \in 00 ิ$.

In onderskeid van verkondiging is die wese van die getuienis dat die waarheid wat bely word teenoor die leuen gehandhaaf word (vgl. Van Rensburg 4.2). So is die belydenis in Jesus 'n getuienis waar die waarheid aangaande Jesus direk teenoor die leuen gestel word. Vir die gelowiges was die belydenis in Jesus dus 'n openbaarmaking van wat hulle aangaande Hom glo.

Om openlik die geloof in Jesus uit te spreek, het vir die belyer dikwels teenstand en 
selfs vervolging van teenstanders ontlok. As sodanig is die belydenis in Jesus 'n getuienis in die sin van martelaarskap. Hiervan dien Johannes 9:22 as voorbeeld: "Die Jode het al ooreengekom dat as iemand Hom as die Christus bely, hy uit die sinagoge verban sou word." In Johannes 12:42 word vermeld dat baie van die owerstes in Hom geglo het maar ter wille van die Fariseërs dit nie bely het nie, om nie uit die sinagoge geban te word nie. Die owerstes was dus nie bereid om hulle geloof in Jesus as 'n belydenis uit te spreek nie aangesien die belydenis in wese 'n getuienis sou wees.

In die Evangelies en Handelinge het die belydenis aangaande Jesus dus per geleentheid 'n apologeties-polemiese karakter. By Jesus se verhoor was die belydenis in Jesus juis die polemiese kern van die verhoor. Die hoëpriester vra uitdruklik en by herhaling die vraag: "Is U die Christus, die Seun van God?", waarop Jesus getuig: "Ek is" (Mark. 14:61-62). Ook Petrus se Pinkstertoespraak dra 'n apologeties-polemiese karakter. As antwoord op die vyandige gespot van die omstanders roep Petrus uit: "Laat die hele huis van Israel dan weet dat God Hom Here en Christus gemaak het, hierdie Jesus wat julle gekruisig het" (Hand. 2:36).

Uit die voorafgaande is dit duidelik dat daar by 'n opname van die voorkoms van Jesus-belydenisse in die Evangelies en Handelinge deeglik rekening gehou moet word met die feit dat belydenisse soms in die vorm van 'n erkenning, soms in die vorm van verkondiging, en soms in die vorm van 'n getuienis voorkom.

\section{DIE INHOUD VAN DIE BELYDENIS}

\subsection{Formuleringe van die belydenis}

Die feit dat 50 belydenisuitsprake in die Evangelies en Handelinge voorkom (vgl. 2 hicrbo) beteken nie dat daar 50 verskillende belydenisse aangaande Jesus voorkom nie. Daar is veelvuldige herhalings van formuleringe. Gevolglik verteenwoordig die 50 uitsprake maar 'n totaal van 14 verskillende belydenisformuleringe aangaande Jesus. Hulle is die volgende:

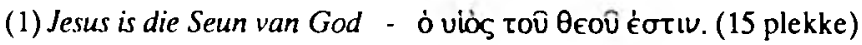

As direkte belydenis (3x): Matt. 14:33; Mark. 15:39; Hand. 9:20.

As geimpliseerde belydenis (12x): Matt. 4:3,6; 17:5; 27:40,43; Mark. 3:17; 9:7;

Luk. $4: 3,9 ; 9: 35 ; 22: 70$; Joh. 10:36. 


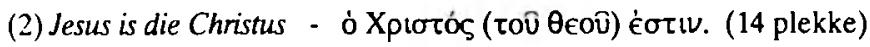

As direkte belydenis (7x): Mark. 8:29; Luk. 9:20; Joh. 7:41; Hand. 5:42; 17:3; 18:5; 18:28.

As geïmpliseerde belydenis (7x): Matt. 16:20; 27:17,22; Luk. 23:35; Joh. 1:20;

$7: 26 ; 9: 22$.

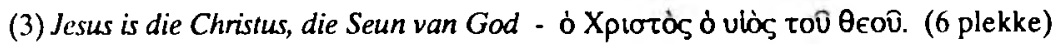

As direkte belydenis (2x): Matt. 16:16; Joh. 11:27.

As geimpliseerde belydenis (4x): Matt. 26:63; Mark. 14:61; Luk. 4:41; Joh. 20:31.

(4) Jesus is die Here - ó kúplos (1 plek)

As geimpliseerde belydenis: Hand. 9:5 (22:8; 25:15).

(5) Jesus is Here en God - ó kúplos kal ò Өєós. (1 plek)

As direkte belydenis: Joh. 20:28.

(6) Jesus is Here en Christus - kúplos kà̀ Xpıotós. (1 plek)

As direkte belydenis: Hand. 2:36.

(7) Jesus is die Messias - ò Meorias. (1 plek)

Geïmpliseerde belydenis: Joh. 1:41.

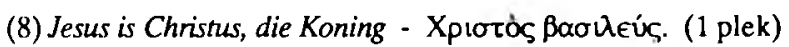

As geimpliseerde belydenis: Luk. 23:2.

(9) Jesus is die Koning van die Jode - ò Baoutù

As geimpliseerde belydenis: Joh. 18:33; 19:19-21.

(10) Jesus is die Seun van Dawid - ò vlò tỗ Aavíi. (1 plek)

As geimpliseerde belydenis: Matt. 11:23.

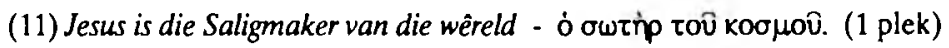

As direkte belydenis: Joh. 4:42.

(12) Jesus is die Lam van God wat die sonde van die wêreld wegneem - $\dot{0} \dot{\alpha} \mu \nu \dot{\alpha}_{\zeta}$ tôิ $\theta \in$ ô. (1 plek)

As direkte belydenis: Joh. 1:29. 
(13) Jesus is die Heilige van God - ò áy

As direkte belydenis: Joh. 6:69.

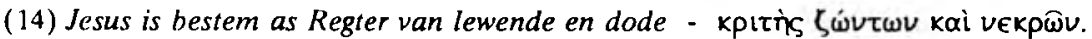
(1 plek)

As direkte belydenis: Hand. 10:42.

4.2 Die sentrale inhoud van die iveiyuieuisist

'n Baie belangrike feit wat uit bostaande 14 formuleringe blyk, is dat al die belydenisse in die Evangelies en Handelinge een saak tot inhoud het, naamlik wie Jesus is: $\mathrm{Hy}$ is die Seun van God, die Christus; die Here, die Messias, ensovoorts. Die standpunt van Ebeling (1967:245) dat Jesus slegs die grond en die bron van die geloof in die vroeë kerk is en nie self ook die inhoud van die geloof is nie, word dus alreeds deur die belydenisse wat in die Evangelies en Handelinge opgeteken is, weerlê. Al hierdie belydenisuitsprake het Jesus tot inhoud - wie Hy is. Uitgaande daarvan dat belydenisuitsprake direkte aanduiding is van dit wat die gelowiges glo (vgl. Van Rensburg 4.2), is dit dus uit die Evangelies en Handelinge duidelik dat Jesus die inhoud van die geloof van die vroeë kerk was.

Die wesentlike inhoud van elke Jesus-belydenis is inderwaarheid 'n antwoord op die vraag van Jesus aan sy dissipels (Matt. 16:15): "Julle, wie sê julle is Ek?" Op hierdie vraag sou meer as een belydenis geformuleer kon word. Selfs Petrus se antwoord op Jesus se vraag word in die drie Sinoptiese Evangelies nie presies eenders geformuleer nie (Matt. 16:16; Mark. 8:29; Luk. 9:20). Inderwaarheid sou elk van die bostaande 14 formuleringe as antwoord kon dien op Jesus se vraag: "Wie sê julle is Ek?"

Dit is opvallend dat elk van die belydenisse geformuleer word in terme van 'n titel waarmee Jesus benoem word. Combrinck (1980:87) wys daarop dat die vroeë Christene vir hulle besinning oor die vraag na wie Jesus is, gebruik gemaak het van titels en begrippe wat aan hulle bekend was. Die belydenisse aangaande Jesus in die Evangelies en Handelinge word dus geformuleer by wyse van titels wat aan Hom verbind word, waarmee erken of getuig of verkondig word wie $\mathrm{Hy}$ is.

\subsection{Kernbelydenisse}

Van naderby beskou is ook die 14 geïdentifiseerde belydenisformuleringe nie 14 verskillende belydenisse oor Jesus nie. Al word Jesus met 14 verskillende titels benoem, het verskeie van hierdie titels dieselfde of feitlik dieselfde belydenis tot 
inhoud. So is die belydenis dat Jesus die Christus is (2) wesentlik dieselfde as die belydenis dat $\mathrm{Hy}$ die Messias is (7) $)^{9}$ en dit oorvleuel grootliks met die belydenis dat $\mathrm{Hy}$ die Heilige van God is (13) ${ }^{10}$. Desgelyks is die belydenis dat Jesus die Here is (4) wesentlik dieselfde as die belydenis dat Hy die Koning is (8) of die Koning van die Jode (9) of die Seun van Dawid (10) ${ }^{11}$. Dat Hy die Lam van God is wat die sonde van die wêreld wegneem, (12) oorvleuel met die belydenis dat Hy die Saligmaker van die wêreld is (11).

Sodoende kan die belydenisse in die Evangelies en Handelinge tot hoofsaaklik drie kernbelydenisse gereduseer word:

* Jesus is die Seun van God (nommers 1 en 3 hierbo).

* Jesus is die Christus (nommers 2, 3, 6, 7, 8, 12 en 13 hierbo).

- Jesus is die Here (nommers 4, 5, 6, 8, 9 en 10 hierbo).

Hierdie drie belydenisse kom by herhaling voor en kan beskou word as die drie sentrale belydenisse aangaande Jesus in die Evangelies en Handelinge. Daar is egter nog drie belydenisse oor Hom wat elk eenmalig voorkom:

* Jesus is God (Joh. 20:28; nommer 5 hierbo).

* Jesus is ons Verlosser (Joh. 4:42; nommer 11 hierbo, en moontlik ook 12).

* Jesus is bestem as Regter van lewende en dode (Hand. 10:42; nommer 14 hierbo).

\subsection{Die verhouding tussen die kernbelydenisse}

Neufeld $(1963: 105,125)$ kom tot die gevolgtrekking dat die basiese belydenis van die

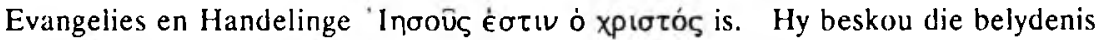

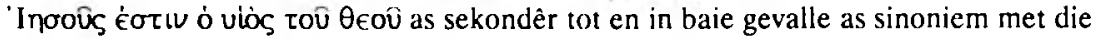
Christus-belydenis. Floor (1982:24) bevind weer dat die belydenis van Jesus as die Seun van God van primère belang is.

\footnotetext{
${ }^{9}$ Messias is bloot dic Hebrecus vir Xpıotós en word ook in Joh. 1:41 so vertaal.

${ }^{10}$ Die Heilige van God betcken die Een wat deur God afgesonder is. Jesus was juis deur God afgesonder vir sy Messiaanse taak. As sodanig is die Heilige van God dus 'n Messiaanse titcl (vgl. Grosheide, 1950:490).

"Weliswaar het baic van diegenc wat Jesus as Koning van die Jode of as Seun van Dawid bely/ontken het, ' $n$ aardsc koning in gedagte gehad volgens die Joodse aardse Messiasverwagting. Hierdie aardse Messiasverwagting doen egter nie afbreuk aan die feit dat $\mathrm{Hy}$ as kúpıos Koning van die Koninkryk beskou is nic. Vgl. in hierdie verband Hahn, 1963:278-279.
} 
Wat die Evangelies en Handelinge betref, is dit egter nie moontlik om aan ò die Christus-belydenis of die Seun-van-God-belydenis primaat te verleen nie. Die twee belydenisse kom feitlik ewe veel kere in die Evangelies en Handelinge voor (vgl 3. hierbo). Nie een van die twee belydenisse het die ander voorafgegaan nie: in Matteus en Johannes is die Seun-van-God-belydenis die eerste wat opgeteken is (Matt. 14:33; Joh. 1:49), in Markus en Lukas die Christus-belydenis (Mark. 8:29; Luk. 9:20). Die twee belydenisse moet dus as twee naasmekaarstaande kernbelydenisse gehandhaaf word.

Met die stelling van Neufeld (1963:125) dat die Christus-belydenis en die Seun-vanGod-belydenis dikwels sinoniem is kan ook nie akkoord gegaan word nie. Marcus (1989:138-140) dui oortuigend uit die Joodse literatuur aan dat die Christus-titel en die Seun-van-God-titel nie as sinonieme beskou kan word nie, maar dat laasgenoemde in die Evangelies inderwaarheid as kwalifikasie van eersgenoemde gebruik word. Boonop is die twee titels as belydenisse verskillend gerig: In die Christus-belydenis staan Jesus se Goddelike opdrag gewoonlik sentraal (Heidelbergse Kategismus, Sondag 12) en in die Seun-van-God-belydenis sy Goddelike wese (Heidelbergse Kategismus, Sondag 13). Die Christus-titel wys heen na Jesus wat na die wêreld gestuur is om die toorn, die oordeel en die vloek van die mensdom te dra, en bereik sy hoogtepunt in die feitelike heilsgebeure van kruis en opstanding (Hahn, 1963:189-218; Floor, 1982:60). Die titel Seun van God wys op die unieke relasie wat daar tussen Jesus en sy Vader bestaan, waarby inbegrepe is dat Hy met Goddelike gesag beklee is en optree (Hahn, 1963:333; Floor, 1982:26-27). Die twee titels het dus elk tot inhoud ' $n$ belydenis wat in die Evangelies en Handelinge naas mekaar en aanvullend tot mekaar bely word.

Die twee belydenisse verteenwoordig ook nie twee verskillende tradisies aangaande Jesus nie en het ook nie die een uit die ander ontwikkel nie, maar is uit die staanspoor naas mekaar bely. Blyke hiervan word gevind in die talle plekke in die Evangelies waar die twee belydenisse aan mekaar verbind word: Jesus is die Christus, die Seun van God (vergelyk veral Petrus se belydenisuitspraak in Matteus 16:16).

Wel opvallend is die voorkoms van die belydenis van Jesus as xúplos (Here) in vergelyking met die Seun-van-God-belydenis. Die belydenis van Jesus as Seun van God kom regdeur die vier Evangelies voor, maar net een keer in Handelinge, aan die begin van Paulus se prediking (Hand. 9:20). Hierteenoor kom die belydenis van Jesus as Here verskeie kere in Handelinge voor, maar slegs een keer in die Evangelies, en dit 
boonop ná Jesus se opstanding, aan die einde van Jesus se optrede op aarde (Joh. 20:28). Hieruit is afleibaar dat die belydenis van Jesus as ulòs toû $\theta \in o v ̂$ van die Evangelies na Handelinge oorgegaan het in die belydenis van Jesus as kúpıs.

Sommige geleerdes is van mening dat daar nie eintlik sprake is van 'n oorgang van een belydenis na 'n ander is nie, maar dat die Seun-van-God-belydenis en die xúplosbelydenis bloot die gevolg van verskillende voorkeure van die evangeliste is (vgl. De Villiers, 1980:232). De Villiers (1980:233) dui egter aan dat persoonlike voorkeur by die evangeliste wel 'n rol gespeel het, maar dat Jesus tog in Handelinge duideliker as kúplos bely word omdat sy heerskappy na sy opstanding onthul is. Te midde van die feit dat daar by elk van die evangeliste 'n eie voorkeur ten opsigte van die Christologiese titels te bespeur is (vgl. Combrinck, 1980:88), is daar in die onderskeie titels dikwels dieselfde belydenis opgesluit (vgl. 4.3 hierbo). Weliswaar weerspieël die oorgang van die Seun-van-God-belydenis na die kúplos-belydenis die openbaringshistoriese voortgang van Jesus se optrede op aarde. Voor sy opstanding word Jesus bely as Seun van God. Na sy opstanding word Hy bely as Here.

As Seun van God was Jesus die Een in wie God die glorie van sy Koninkryk sou herstel deur die oorwinning oor Satan as teëkoning (Floor, 1982:54). Daarom is dit nie vreemd nie dat die duiwel en die demone hulle konsekwent rig teen die belydenis dat Jesus die Seun van God is (Matt. 4:3,6; Mark. 3:11; Luk. 4:3,9,41). Hulle weet dat die Seun van God bestem is om die oorwinning te behaal (Jak. 2:19). Die belydenis dat Jesus die Seun van God is wys dus in 'n sekere sin vorentoe na die deurbraak van die Koninkryk van God by die kruis en opstanding.

Jesus se opstanding uit die dood was die kairos waarby die Koningsheerskappy van God glorieryk deurgebreek het. Na sy opstanding is Jesus steeds Seun van God (Hand. 9:20), maar nou geopenbaar in sy volle heerlikheid as die Oorwinnaar, die Kúploc wat regeer oor lewe en dood. Daarom bely Thomas na Jesus se opstanding: "My Here en my God" (Joh. 20:28). As Kúplos wat die oorwinning oor die teëkoning behaal het, bestyg Jesus ook sy koninklike troon met hemelvaart. Daarna verklaar Petrus in sy Pinkstertoespraak: "Laat dan die hele huis van Israel sekerlik weet dat God Hom Here en Christus gemaak het, hierdie Jesus wat julle gekruisig het" (Hand. 2:36).

Die oorblywende drie belydenisse wat elk eenmalig in die Evangelies en Handelinge voorkom (Jesus is God, Jesus is ons Verlosser, Jesus is bestem as Regter van lewende en dode; vgl. 3.2 hierbo), staan elk ook in 'n besondere verhouding tot die drie kernbelydenisse. 
In 'n sekere sin voer die belydenis dat Jesus God is (Joh. 20:28), die belydenis van Hom as die Seun van God en as kúploc tot 'n hoogtepunt (vgl. Cullmann,1966:244). Waar die Seun-van-God-belydenis die unieke relasie van Vader-Seun binne die Drieeenheid beklemtoon, laat die belydenis dat Jesus God is, die fokus na die wesenseenheid van die Vader en die Seun verskuif. Hierdie belydenis sluit ten nouste aan by ander Skrifuitsprake in verband met die wesenseenheid van die Vader en die Seun, soos Johannes 1:1 en Johannes 17:22.

Waar Jesus bely word as Verlosser (Joh. 4:42) en as Regter van die lewende en die dode (Hand. 10:42), verskuif die klem ietwat van wie Jesus is na wat Jesus doen. As sodanig sluit hierdie twee belydenisse wesentlik aan by die belydenis van Jesus as die Christus en Jesus as die Here. Jesus het as Christus na die wêreld gekom met die opdrag om die wêreld te verlos van sy sonde. Daarom is die belydenis van Jesus as Verlosser van die wêreld inderwaarheid'n verbesondering van die belydenis van Jesus as die Christus. Desgelyks is die belydenis van Jesus as Regter van die lewende en die dode 'n besondere eskatologiese toespitsing van die belydenis van Jesus as kúptos. Jesus het as Kúptoç na die hemel opgevaar, nie net om daarvandaan te regeer nie, maar om ook daarvandaan weer te kom om die lewende en die dode te oordeel.

\section{DIE OORSPRONG VAN DIE BELYDENIS}

Ebeling (1967:245) beskou Jesus as die grond en die oorsprong van die geloof. Daarmee bedoel hy dat die voorbeeld wat Jesus gestel het die stimulus was wat sy dissipels daartoe beweeg het om te glo (238). Onder geloof verstaan Ebeling egter nie 'n geloof in Jesus nic, maar 'n geloof in sy mag - dat Hy alles kan doen (1967:241). As bewysvoering hiervoor voer Ebeling aan dat Jesus telkemale by sy wonders verklaar: "Jou geloof het jou gered!" Jesus is dus ook vir die hedendaagse gelowige die oorsprong van die geloof wanneer daar 'n ontmoeting met Jesus plaasvind, waardeur die mens die stimulus tot geloof ontvang (251).

In aansluiting by die Formgeschichte gaan Wengst (1967:99-104) daarvan uit dat die belydenisse aangaande Jesus wat in die Evangelies opgeteken is, nie 'n historiese basis het nie, maar dat dit later as antwoord op die dwaalleer van die Judaïsme in die Evangelies "ingeskryf" is. Dic dwaalleraars het betwis dat Jesus die Christus, die Seun van God, is. By wyse van verdediging het skrywers van die vroeë kerk uitdruklike belydenisse van Jesus as die (hristus en Seun van God in die Evangelies ingevoeg (vgl. ook Cullmann, 1943:33-3.5). Hierdie uitgangspunt van Wengst lei onvermydelik tot 
die gevolgtrekking dat die Jesus-belydenisse hul oorsprong by die vroeg-Christelike kerk het (1967:109).

Kuitert (1977:147-155) is van mening dat die belydenis sy oorsprong by die mens het. Vir Kuitert is daar geen twyfel oor die bestaan van God nie, maar vir hom is 'n belangrike uitgangspunt die feit dat niemand God ooit gesien het nie (Joh. 1:18). Daarom kom elke mens wat na God soek tot 'n eie ontwerp van God, wat Kuitert "zoekontwerp" noem (147). Mense neem in hulle eie ervaringswerreld dinge waar wat elkeen op subjektiewe wyse as "spore van God" (h)erken (149). Vanuit dit wat die mens as "spore van God" beskou, kom hy dan daartoe "om te zeggen wie God is" (149). Die mens se subjektiewe ervaring is dus oorsprong van dit wat hy aangaande God bely en sy belydenis is produk van sy eie zoekontwerp. So het ook die Christelike belydenis aangaande Jesus sy oorsprong by die mens. Die Bybelse belydenisse oor wie God (en derhalwe ook Jesus) is (155), is vir Kuitert bloot die eerste produkte van die Christelike zoekontwerp en kan daarom nie op sigself kriterium vir die waarheid wees nie (174).

In die soeke na die antwoord op die vraag na die oorsprong van die belydenis en die geloof wys Kuitert 'n beroep op die openbaring kategories af (1977:155). Veel eerder beroep hy hom op die filosofiese denksisteem van Kierkegaard: "De subjectiviteit is de waarheid" (Kuitert, 1977:151). Hierteenoor moet gestel word dat die waarheid in verband met die oorsprong van die belydenis en die geloof veel eerder 'n geloofsaak is as 'n saak wat vanuit filosofiese denksisteme bewysbaar is. Derhalwe moet die antwoord op die vraag na die oorsprong van die belydenis in die Skrif self gesoek word. In die Evangelies is die kwessie van die oorsprong van die belydenis en die geloof dikwels ter sprake, veral in die Johannesevangelie. 'n Oorsig oor sodanige Skrifuitsprake bring die lig wat die Skrif self op hierdie vraagstuk werp, na vore.

In Johannes 1:33 getuig Johannes die Doper hoe hy weet en getuig dat Jesus die Lam van God (1:29), die Seun van God (1:34), is. Hy sê: "Ek het Hom nie geken nie; maar Hy wat my gestuur het om met water te doop, Hy het aan my gesè: ..." Hiervolgens blyk dit dat God self die direkte oorsprong van die belydenis aangaande Jesus is. Dit korreleer met Jesus se woorde na die belydenis van Petrus (Matt. 16:17): "Salig is jy, Simon Bar-Jona, want vlees en bloed het dit nie aan jou geopenbaar nie, maar my Vader wat in die hemele is."

Dit blyk egter ook duidelik uit die Evangelies dat nie elke belydenis aangaande Jesus die produk van 'n direkte, onmiddellike Godsopenbaring is nie. In Johannes 4:42 sê die Samaritane vir die vrou: "Ons glo nie meer op grond van wat jy gesê het nie, want 
ons het self gehoor en ons weet dat Hy waarlik die Christus, die Saligmaker van die wêreld, is." God het die waarheid aangaande Jesus dus deur middel van die woorde van Jesus aan hulle geopenbaar.

Nie net deur Jesus se woorde nie maar ook deur sy dade openbaar God die waarheid wat aangaande Hom bely moet word. Dit blyk uit Jesus se woorde aan Natanael (Joh. 1:51): "Glo jy omdat Ek vir jou gesê het: Ek het jou onder die vyeboom gesien? Jy sal groter dinge sien as dit." Dit is opvaliend hoeveel van die belydenisse wat in die Evangelies opgeteken is, direk op een van Jesus se wonders volg. As voorbeeld hiervan dien die belydenis van Jesus se dissipels nadat Hy die storm stilgemaak het (Matt. 14:33): "Waarlik, $U$ is die Seun van God!"

$\mathrm{Na}$ Jesus se opstanding en hemelvaart bring God die waarheid om aangaande Jesus te bely nie meer langs die weg van aanskouing by die gelowige uit nie. Duidelike getuienis hiervan word gevind in Johannes 20 in Jesus se antwoord op die belydenis van Thomas (20:29): "Omdat jy My gesien het, Thomas, het jy geglo; salig is die wat nie gesien het nie en tog geglo het." Voortaan word die Skrifgeworde Woord die weg waarlangs God Jesus openbaar as die Een wat bely moet word as die Seun van God. Dit blyk uit Johannes se woorde (20:30,31): "Nog baie ander tekens het Jesus voor sy dissipels gedoen wat in hierdie boek nie beskrywe is nie; maar hierdie is beskrywe, dat julle kan glo dat Jesus die Christus is, die Seun van God ..."

Dit blyk dus duidelik uit getuienis van die Evangelies dat God self die oorsprong van die belydenis aangaande Jesus is. Die kerk is nie die oorsprong of bron van die belydenis aangaande Jesus nie (Wengst, 1967:99-104). Die belydenis is ook nie deur die mens ontwerp om sy soeke na wie God is te bevredig nie (Kuitert, 1977:147). Die belydenis is selfs nie die produk van Jesus se optrede of produk van 'n eksistensiële ontmoeting met Jesus nie (Ebeling, 1967:245). God is Self die bron van die belydenis aangaande Jesus. Deur die getuienis van sy Heilige Gees in die mensehart bring $\mathbf{H y}$ mense daartoe om Jesus te bely as sy Seun, die Christus, ons Here en ons God. Die getuienis van die Heilige Gees is egter nie onmiddellik nie mar vind wel plaas deur middel van sy Woord, wat deur sy diensknegte te boek gestel is en verkondig word.

\section{DIE VERHOUDING TUSSEN DIE JESUS-BELYDENIS EN GELOOF}

Daar bestaan 'n direkte verband tussen die Jesus-belydenis en die geloof. Dit wat die mens bely is ' $n$ openbaarmaking van wat hy in sy hart glo. Romeine 10:9 bring dit 
onder woorde: "As jy met jou mond die Here Jesus bely en met jou hart glo dat God Hom uit die dode opgewek het, sal jy gered word."

Die belydenisuitsprake in die Evangelies en Handelinge is daarom ook 'n openbaarmaking van wat die belyer aangaande Jesus glo; 'n belydenis wie $\mathrm{Hy}$ is. Die belydenis in Jesus staan ook nie los van die geloof in God nie. Die eenheid van die Vader en die Seun (Joh. 17:22) beteken ook dat die geloof in die Vader en die Seun een geloof is. Daarom sè Jesus uitdruklik in Johannes 14:1: "Glo in God, glo ook in My."

Hierdie verband tussen die Jesus-belydenis en die geloof het daartoe gelei dat die kerk die Jesus-belydenis as 'n toets vir persoonlike geloofsoortuiging beskou het (vgl. Neufeld, 1963:107). Hiervan is 1 Johannes 4:2 'n duidelike getuienis: "Hieraan ken julle die Gees van God: elke gees wat bely dat Jesus Christus in die vlees gekom het, is uit God..."

\section{DIE VERHOUDING TUSSEN DIE JESUS-BELYDENIS EN DIE BELYDENISSKRIFTE}

Na aanleiding van 1 Johannes 4:2 en Johannes 20:19-28 stel Neufeld (1977:106) dat die geloofsbelydenis die ware geloof en teenwoordigheid van die Gees in die vroeë kerk verteenwoordig het. Die Jesus-belydenis is dus nie net 'n openbaarmaking van die individuele geloof nie maar ook van die kollektiewe geloof van die gelowiges wat God in sy kerk vergader. Daarom is die belydenis van die waarheid aangaande Jesus Christus een van die merktekens van die ware kerk (Nederlandse Geloofsbelydenis, artikel 29) en ook 'n wapen wat teen dwaalleer aangewend kon word (Titus 1:7-14; vgl. ook Neufeld, 1963:107).

In die geskiedenis het die kollektiewe geloof van die kerk tot openbaring gekom in die belydenisskrifte. Aangesien die belydenis nie sy oorsprong by die kerk het nie maar by God self, wat deur die werking van sy Gees en Woord die mens tot belydenis bring, mag ook die belydenisskrifte nie as blote produk van die kerk beskou word nie maar wel as produk van die werking van die Woord en die Gees. Dit beteken dat die belydenisskrifte niks anders is of mag wees nie as 'n naspreke van die waarheid wat God in sy Woord openbaar.

Wat die belydenis aangaande Jesus betref, beteken dit dat die belydenisskrifte dit wat in die Bybel aangaande Jesus bely word, moet opvang en weergee. Teen hierdie agtergrond is dit die opgawe van hierdie artikel om na te gaan of dit wat in die 
Evangelies en Handelinge as Godgegewe belydenis aangaande Jesus bely word, ook in die Apostoliese Geloofsbelydenis, die Geloofsbelydenis van Nicea en dié van Atanasius bely word, asook in die Nederlandse Geloofsbelydenis, die Heidelbergse Kategismus en die Dordtse Lecrreëls.

Vanuit die opname van die Jesus-belydenisse in die Evangelies en Handelinge is in hierdie artikel aangetoon dat die Jesus-belydenisse in drie kernbelydenisse saamtrek, naamlik dat Hy die Scun van God is, dat Hy die Christus is, en dat Hy die Here is (vgl. 4.3 hierbo). Verder is nog drie belydenisse in die Evangelies en Handelinge aangetoon wat as besondere toespitsings van die kernbelydenisse beskou kan word, naamlik dat Jesus God is, dat Hy ons Verlosser is, en dat Hy kom as Regter om die lewende en die dode te oordeel.

Wanneer die oudste belydienisskrif, die Apostolicum, onder oë geneem word, is dit opvallend dat die drie kernbelydenisse aangaande Jesus direk en uitdruklik bely word: ". . . en in Jesus Christus (1), sy eniggebore Seun (2), ons Here (3)". Die wesentlike belydenis aangaande Jesus soos ons dit in die Evangelies en Handelinge ontvang het, is dus in die Apostoliese Geloofsbelydenis teenwoordig. Een van die drie besondere toespitsings is ook daarin opgeneem, naamlik die belydenis dat Jesus "sal kom om te oordeel die lewende en die dodle."

Ook die Belydenis van Nicca begin by die drie kernbelydenisse: " . . en in een Here (1) Jesus Christus (2), die eniggebore Seun van God (3). Hierdie keer word egter twee van die drie besondere toespitsings bygebring, naamlik dat Jesus "ter wille van ons, mense, en ons saligheid neergekom het uit die hemel ..." en dat Hy "weer sal kom met heerlikheid om te oordeel die lewende en die dode".

Die Belydenis van Atanasius latat die klem sterk val op die Godheid van Jesus Christus, en begin dus met een van die besondere toespitsings van die Jesus-belydenis, naamlik dat Hy God is (art. 15). Verder word die drie kernbelydenisse in artikel 30 van dié belydenis saamgevat in die woorde: "So is dan die regte geloof dat ons glo en bely dat ons Mere Jesus Christus, die Scun van God, God is en mens.

Samevattend oor die algemene belydenisskrifte kan dus gesê word dat al drie die belydenisskrifte die drie kernbelydenisse aangaande Jesus bevat. Nie een van die belydenisskrifte bevat egter al drie die besondere toespitsings van die Jesus-belydenis nie, maar elk van die toespitsings kom wel êrens in een van die belydenisskrifte voor. 
In die Nederlandse Geloofsbelydenis kom die belydenis van Jesus as die Seun van God reeds in artikels 8 en 9 voor, maar in besonder in artikel 10, waar bely word dat "Jesus Christus na sy Goddelike natuur die eniggebore Seun van God is". In artikels 9 tot 17 word reeds na Jesus as Christus verwys, terwyl artikels 18 tot en met 23 in besonderhede die belydenis van Jesus as die Christus uiteensit. Die Nederlandse Geloofsbelydenis verwys by herhaling na Jesus as die Here (bv. art. 9, art. 16 en art. 26). Selfs die slotwoorde van hierdie belydenisskrif sluit by die belydenis van Jesus as Here aan (art. 37): "Daarom verwag ons die groot dag met 'n groot verlange om ten volle te geniet die beloftes van God in Jesus Christus, ons Here." Ook die drie besondere toespitsings van die belydenis in die Evangelies en Handelinge, word in die Nederlandse Geloofsbelydenis teruggevind. In artikel 10 word bely dat Jesus God is; in artikels 21, 22 en 23 word Hy uitdruklik as Verlosser en Saligmaker bely; in artikel 37 word Hy bely as Regter oor lewende en dode.

Die Heidelbergse Kategismus behandel in Sondagafdelings 7 tot 22 die Apostoliese Geloofsbelydenis, en handhalaf daarmee die belydenis van Jesus as die Seun van God (vraag en antwoord 33), as die Christus (vraag en antwoord 31) en as die Here (vraag en antwoord 34), asook die belydenis dat Hy kom as Regter om die lewende en die dode te oordeel (vraag en antwoord 52). Die Kategismus sluit ook die ander besondere toespitsings van die belydenis aangaande Jesus in, naamlik dat Hy God is (Sondag 8 en Sondag 18) en dat Hy ons Verlosser en Saligmaker is (Sondag 11).

Ook die Dordtse Leerreëls bely al drie die kernbehydenisse aangaande Jesus soos dit in die Evangelies en Handelinge voorkom. In Hoofstuk 1.2 en Hoofstuk 2.3 en 2.4 van die Leerreëls word bely dat God Jesus as sy eniggebore Seun in die wêreld gestuur het. In Hoofstuk 1.3 en 1.5 en verder aan word na Jesus as Christus verwys, en in Hoofstuk 5.2 word Hy genoem die Lam van God. In Hoofstuk 5.1 word na Hom verwys as ons Here Jesus Christus, en in Hoofstuk 3-4.10 word Jesus ook Here genoem in wie se ryk die verlostes deur God ingebring word. Ook die besondere toespitsings van die kernbelydenisse wat in die Evangelies en Handelinge voorkom, word in die Dordtse Leerreëls aangetref. In Hoofstuk 1.4 en 1.16 en verder aan word na Jesus verwys as ons Saligmaker. In Hoofstuk 2.4 word bely dat Hy as die eniggebore Seun van God van "eenselfde wese met die Vader en die Heilige Gees" is, dit wil sè dat Jesus God is. Hoewel die titel van Regter wat lewende en dode oordeel nie in die Leerreëls direk aan die Persoon van Jesus verbind word nie, word dit tog per implikasie gedoen in Hoofstuk 1.15 waar na die ewige besluit van God verwys word (waarby Vader, Seun en Heilige Gees betrokke is, vgl. Hfst. 2.4), en dan verder gesê word dat die besluit God nie tot bewerker van die sonde stel nie maar "tot 'n verskriklike, onberispelike en regverdige Regter en Wreker daarvan". 
Dit blyk dus dat elk van die drie algemene belydenisskrifte ten minste die drie kernbelydenisse aangaande Jesus bevat, en in 'n mindere of meerdere mate ook die besondere toespitsings daarvan. In die drie besondere belydenisskrifte kom al drie die kernbelydenisse met hulle besondere toespitsings voor.

\section{GEVOLGTREKKING}

Dit blyk dus dat die belydenisse in die Evangelies en Handelinge deurgaans as antwoord dien op die vraig na wie Jesus is. Die belydenisse sentreer in drie kernbelydenisse aangaande Jesus, naamlik dat Hy die Seun van God is, Christus, die Here. Hierdie drie kernbelydenisse word verbesonder deur die belydenis dat Jesus God is, dat Hy ons Verlosser is en dat Hy kom as Regter wat lewende en dode oordeel.

God is Self die bron van die waarheid aangaande Jesus en deur die werking van sy Gees en Woord het Hy die warheid aan die gelowiges gegee om aangaande Jesus te bely. Die belydenis, soos dit veral in die Evangelies en Handelinge voorkom, is dus 'n openbaarmaking van wall die belyer aangaande Jesus glo.

Die belydenisskrifte verwoord die belydenis aangaande Jesus soos dit in die Evangelies en Handelinge tot ons kom, noukeurig en volledig. Hieraan is dit duidelik dat ook die belydenisskrifte nic mar net 'n willekeurige produk van die kerk is nie maar inderwaarheid hulle oorsprong in die Woord van God het.

\section{BIBLIOGRAFIE}

ALAND, K., BLACK, M., MARTINI, CM., METZC;ER, B.M \& WIKCREN, A. (eds.) 1983. The Grecks New Testament (Third corrected edition). Stuttgart: Uniled Bible Sucicties.

BAUER, W. 1958. Gricehisch-Deutsches Worterbuch zu den Schriften des Neuen Testaments und der ubrigen urchristlichen Litcratur. Berlin : Töpclmann.

BLASS, F. \& DEBRUNNER, A. 1975. A Greck grammar of the New Testament and other carly Christian literature, transtated by R.W. Funk. Chicago: University Press.

COMBRINCK, H.J.B 1980). Die Evangclic volgens Matteus : Inleiding en Teologic. (In Du Toit, A.B., red. Handleiding by dic Nuwe Tcstament, Band IV. Pretoria : N.G. Kerkboekhandel. P. 62-108.)

CULLMANN, O. 1943. Dic ersien christlichen Glaubensbekenntnisse. Zurich : Zollikon. 60p.

('ULLMANN, O. 1\%66. Dic Chrislologic des Neuen Testaments. Tübingen : Mohr.

DE VILLIERS, J.L. 1980. Tcologic van dic bock Handelinge. (In Du Toit, A.B., red. Handleiding by dic Nuwc Testament, Band IV. Prctoria : N.G. Kerkbockhandel. p. 219-254.)

DELLING, D.G. 1962. Worship in the New Testament. London : Darton, Longman \& Todd. 191 .

EBELING, D.G. 1\%67. Worl und Glauls. Tubingen: Mohr. 482p. 
FLOOR. L. 1982. Perspekticwe op dic prediking van Paulus. Pretoria : NGKerkboekhandel.

GROSHEIDE, F.W. 1950. Het heilig Evangelic volgens Johannes. Kommentaar op het Nieuwe Testament. Amsterdam: Bottenburg.

HAHN, F, 1963. Christologische Hoheitstitel, Göttingen: Van den Hoeck \& Ruprecht.

HOOKER, M.D. 1989. IIı

KELLY, J.N.D. 1972. Early Christian crecds. London : Longman. 446p.

KITTEL, G. \& FRIEDRICH, G. cds. 1978. Theological dictionary of the New Testament, V. Grand Rapids : Eerdmans.

KUITERT, H.M. 1977. Wat hect geloven? Structuur en herkomst van de christelijke geloofsuitspraken. Baarn : Ten Have. 232p.

LOUW, J.P. \& NIDA, E.A. 1989. (ircek-English lexicon of the New Testament based on semantic domains, 2 vols. New York: United Bible Societies.

MARCUS, J. 1989. Mark 14:61 : "Are you the Messiah-Son-of-God?" Novum Testamentum, 31(2) : 125-141.

MEYER, H.A.W. 1877. Critical and exegelical handbook to the Gospel of Matthew. Critical and exegetical commentary on the New Testament. Edinburgh: T\& T Clark.

MOLLTON, J.H., HOWARD, W.F. \& TURNER, N. 1976. A grammar of New Testament Greek, IV. Style. Edinburgh: T \& T Ctark.

NEUFELD, V.H. 1963. The earliest Christian confessions. New Testament tools and studies, V. Grand Rapids: Eerdmans, 166p.

VAN RENSBURG, J.J.J. 1991. Die begrip bely/belydenis in die Nuwe Testament. In die Skriflig, 25(2):159-174.

WENGST, K. 1967. Christologische Formeln und Lieder des Urchristentums. Bonn : Theinischen F.W.-Universität. $150 \mathrm{p}$ 